\title{
BOYCOTT CHINA? TIME FOR REALITY CHECK AND NO BLABLA
}

\author{
Dr.Satabdi Roy Choudhury \\ Freelance Writer
}

\author{
Dr.Nilotpal Saha \\ Assistant Professor \\ Commerce College Kokrajhar, \\ Assam
}

Article DOI: $\underline{\text { https://doi.org/10.36713/epra5295 }}$

\section{BACKGROUND OF THE STUDY}

Rise of the deadly Corona virus within the Wuhan, China, India-China Galwan Valley Clashes and China's claim over Galwan area, Separatists Movement by Taiwan and Hong Kong (semiindependent island and city located in South China respectively), Issues on Human Rights, Yulin Dog Meat Festival, which spans about 10 days and where thousands of dogs are consumed etc.,all these recent events leads to intense conflict and escalating tension between world and China. But the above discussed events are a one side of a big problem, as many countries across the globe are joining hands against China.Today world is demanding and in fact pushing China to provide the reason behind the origin of corona virus outbreak. The countries like Australia and New Zealand, demanded an investigation and this demand is backed by European Union's Foreign Policy Chief JosepBorrell, who also demanded an independent and scientific explanation against these outbreak of Pandemic. On the other hand countries as Canada, Japan, France, Germany, United Kingdom, New Zealand, Australia and even Nicaragua have pledged and supported to Taiwan's membership in the World Health Organisation (WHO). On this, China threatened these countries for such support, as China considers Taiwan to be one of its provinces. Furthermore, these counties are also abusing China for violating human rights, as United States Senate has approved a bill to sanction China over repression of Uighur Muslims in the Country (Sharma. P, 2020). Therefore, these incidence lead to other countries distance itself from China. The countries as European Union, Australia and even India have tightened their foreign policies and investment rules to prevent local business take over. On top of everything the countries are now following a new trend that is demanding a ban over Chinese products and technologies. Among the products Huawei Company is the most common target. United States has already extended ban on this company for a year, whereas, Japan has set up a 2.2 billion dollar fund to assist their own companies to relocate the production hub anywhere other than China.

Now, at this juncture there is a actual push by politicians right now to boycott made in China goods (Kumar.T, 2016). In India, during second phase of lockdown, Prime Minister NarendraModi, while addressing Nation, clearly gave a message regarding Make in India products. He said the coming of noble corona virus has taught us how local made products was only help available within the country as due to lockdown all foreign exports and imports are stopped. He further, added, the local products are not only our needs, it our responsibility also to promote. In short we have to be "Vocal for the Local" and this have to pave the path of AatmanirbharBharat that is Self-ReliantIndia.

Here, we have to realise that though a new form of Swadeshi Movement is taking shape, but let's take a step back and sit back down to understand the actual reality of the market scenario of world and especially in India. China is India's largest trading partner but not vice-versa. Only 2 to 3 per cent of Chinese exports are from India. So, India's boycott won't dent Chinese economy (Mundra.S, 2016). From electronics to children toys to medicinal raw material, we depend heavily on Chinese Commodities.

\section{Purpose of the Study}

Boycott of specific consumer products is a worldwide and historic phenomenon. In order to encourage local companies and to motivate the investors to dedicate their investments for the good of nation, host countries began to go for boycott foreign products. In India such decision of boycott was also present during pre- independence era, as the history reveals at 1905 after the Bengal partition boycott movement was launched along with Swadeshi movement to encourage Khadi industry against 
British made goods. At present scenario 2020, we Indians are witnessing similar situation evolving against China.

The present study examines the impact of Chinese marketing strategy and trade relations within the world and Indian economy. The paper also depicts the picture of the extent of Chinese commodities and investment within the market and how China became the Asia's one of the largest economy. The Paper tries to analyse the actual circumstances of the market and subsequent ban over Chinese commodities. In other words, author tries to draw our focus on the existing reality of the world's and Indian economic situation, countries interdependence over trade relations and also raises question for too much heightened support of nationalism over social media etc. Ultimately the paper provides comprehensive framework covering all the possibilities regarding how crossing all odds, Indian economy can become independent only by self believe, self-help and self-production.

\section{INTRODUCTION}

\subsection{Chinese Marketing Strategy and Its Trade Relation with the World and Indian Economy:}

With the world's mostpopulous country and Asia's one of the largest economy, China has established itself as the global economic power house within a few decades. Chinese industrial revolution, which started 35 years ago, was the most important phenomenon. Today, China is igniting new growth across Asia, Latin America, Africa and even the industrial west due to its capacity of raw material, energy, trade and capital flow (Wen.Y, 2016). Chinese economy thrives as a manufacturing hub and nations product seems to be everywhere, majority of tags, labels and stickers on a variety of goods proclaim that they are "Made in China", that's why it is quite understandable as we often wonder why everything is made in China? From such question a view point also arises, that most of the products in the market are made in China, it may be due to abundance of cheap labour that brings down the production cost. But there are much more added points, such as a strong business eco-system, lack of regulatory compliances, low taxes and duties and competitive currency practices (Bajpai.P, 2020). These business points or in other words business network developed in China only in 20 years and transformed into organic growth to rapid expansion through investment, acquisition, entrepreneurship and incubation of new ventures, continuous innovation and internationalisations (Greeven.M.J \& Wei.W, 2017).

China has discovered one secret recipe which fundamentally differs from many western working policies which has paved its way for such amazing growth. The channel- straddlingis one such strategy where, different gigantic brands like Baidu, Alibaba and Tencent (in short BAT) followed by Xiaomi and LeEco (XL) which operating in the world market, belongs to same business network. Such marketing strategy becomes a world of closed loop and the vast ecosystem of BAT and XL allows an integrated view of customers within the market. By using such integrated view the marketers latter creates programming sites for shopping, gaming, news, reading etc., creating more contextual relevant engagement. In other words the Chinese marketing approach starts with thinking about content, information and knowledge that could be engaging and shared which is very different from other countries marketing approach which is basically based upon advertising and price promotion (Kangwon National University, 20162017).Moreover, Chinese companies don't waste time on research and innovation; rather they simply copy the technology from advance countries and starts producing their own goods. Such approach saves the costs for researchand development (R\&D).

Today, Chinese rapid growth has puzzled many people, including economist, on how China became leading, creating and disrupting markets for corporate executives and professionals in global business. As Chinese economy grows fast China has also developed many trading partners in the world.Over the past several decades, Chinese trade has expanded at a breakneck pace. In 1995, the value of China's imports and exports of goods totalled $\$ 280.9$ billion or $3 \%$ of global trade. By 2018 , its total trade in goods had jumped to $\$ 4.6$ trillion or $12.4 \%$ of global trade. The US is the world's secondlargest trader at $11.5 \%$ of total trade, followed by Germany at $7.7 \%$. The value of China's exports in goods annually surpasses the amount it imports from the rest of the world. In 2018, China exported \$2.49 trillion in goods while it imported \$2.13 trillion. The majority of China's surplus comes from trade with the US and Hong Kong. Despite significant trade tensions between Beijing and Washington, China's trade with the US expanded in 2018 compared to 2017, and its exports to the US reached record levels. China exported $\$ 480$ billion worth of goods to the US in 2018 (19\% of all its exports), but only imported $\$ 156$ billion ( $7.3 \%$ of all its imports). In the case of Hong Kong, China exported \$303 billion in $2017(12.2 \%$ of total exports) and imported just $\$ 9$ billion, that is $0.4 \%$ of total imports (CSIS, 17th March, 2020).

If we shift our focus upon the India- China Trade relation, therapid expansion of India-China bilateral trade since the beginning propelled China to emerge as our largest goods trading partner by 2008 , a position which China continues to hold today. Since the beginning of the previous decades, bilateral trade between the two countries recorded exponential 
growth. In 2011, bilateral trade reached US\$ 73.9 billion, before dipping to US\$ 66 billion in 2012 and rebounding to US\$ 71.65 in 2015 . For last three years, the bilateral trade has registered robust twodigit growth. For the year 2018, bilateral trade increased by $13.34 \%$ year-on-year to reach US\$ 95.7 billion, with India's exports rebounding to US\$ 18.83 billion registering positive growth of $15.21 \%$ yearon-year after 3 years' continuous decline and growth of $39.11 \%$ in 2017. In 2018 India's imports from China grew by $12.89 \%$ to US $\$ 76.87$ billion while the trade deficit widened to $\$ 58.04$ billion (Embassy of India, Beijing, China, 2019).Below the table-1, lists the imports and exports of goods between India and China.

Table: 1: Bilateral Trade between India and China

\begin{tabular}{|l|l|}
\hline \multicolumn{1}{|c|}{ India Imports from China } & \multicolumn{1}{c|}{ China Imports from India } \\
\hline Electric Machinery, & Organic Chemicals; \\
Sound Equipment, & Ores, Slag and Ash; \\
Television Equipment and parts thereof; & Natural Pearls, \\
Nuclear Reactors, Boilers, & Precious stones \\
Machinery and Mechanical Appliances and Parts; & and Precious metals; \\
Organic Chemicals; & Cotton, Including Yarns and Woven \\
Plastics and articles thereof; & Fabrics thereof; \\
Articles of Iron and Steel & Fish and Crustaceans, Molluscs and Other Aquatic \\
& Invertebrates \\
\hline
\end{tabular}

(Source: Embassy of India, Beijing, China, 2019)

From the above table it can be said that, the booming bilateral trade has come to be the strongest pillar of China-India rapprochement. This has not only since overtaken the pace of political confidencebuilding but also has a substantial impact on the mutual perceptions of both the countries. The border trade has especially brought about a noticeable transformation within the remote and problematic border regions. This has contributed to overall tranquillity and peace in the area and has as well facilitated progress in border negotiations. This boom in trade has also introduced new trends. The two countries are no longer only recipients on foreign direct investment but have entered into a new phase of being investors, both mutually as in other regions. There for, China and India today represent Asia's two largest and most dynamic societies which are emerging as new trend setters in international relations. Especially, with their annual GDP growth rates standing respectively at $9.1 \%$ and $8.5 \%$ for 2003 and at $9.5 \%$ and $6.9 \%$ for 2004 , China and India have since come to be recognised as the fastest growing economies. According to World Bank estimates, and assessed on the basis of purchasing power parity, China and India have already become respectively the second and fourth largest economies of the world surpassing developed countries (Singh.S, 25th June, 2018).

Recently, with the outbreak of the Corona Virus, the trade between China and India fell 12.4 per cent year-on-year to USD 12 billion in the first two months of the year 2020. The lockdowns in both the countries due to Covid-19 is expected to badly affect the bilateral trade which declined by three billion dollar last year to USD 92.68 billion from USD 95.7 billion in 2018 (The Economic Times, $3^{\text {rd }}$ April, 2020).

\subsection{Presence of Chinese Commodities within the World and Indian Market}

China's mind-blowing growth in the last three decades has surprised the world. By making massive trade and investment deals with Latin America and Africa it has established its presence, as a super power along with European Union and United States. China's rise is always backed by its huge production houses within its country. China manufactures world's $80 \%$ of Air Conditioner, $70 \%$ Mobile Phones, $60 \%$ Shoes, $74 \%$ Solar Cells, 60 $\%$ Cement,45 \% Ships and $50 \%$ Steel (Bada Business, 10 $0^{\text {th }}$ August, 2019). One of the major drivers of such huge production by China is the massive network of factories that churned out everything for consumers all over the world.China's entry into the World Trade Organization in 2001 helped it cement its status as the world's factory and largest trader. In the McKinsey report which analysed 186 countries, China was found to be the largest export destination for 33 nations and the largest source of imports for 65 (Lee.Y.N, 23 ${ }^{\text {rd }}$ Sept, 2019). Today,Chinese exports totalled $\$ 2.06$ trillion in 2016 , a dip of $13 \%$ from 2015 's $\$ 2.37$ trillion. Therefore, China's export commodities can be listed as- 


\begin{tabular}{|c|c|}
\hline \multicolumn{2}{|c|}{ Table: 2: List of Chinese Products Exported within the World } \\
\hline $\begin{array}{l}\text { Machines (43\%):- Computers }(6.6 \%), \\
\text { Broadcasting equipment (5.6\%), } \\
\text { Telephones (4.1\%) } \\
\text { Textiles }(12 \%) \text { - Women's sweaters, suits, } \\
\text { etc. } \\
\text { - Metals }(7.3 \%) \text { - Steel bars, iron } \\
\text { structures, etc. } \\
\text { Optical, Technical and Medical apparatus } \\
(2.9 \%)\end{array}$ & 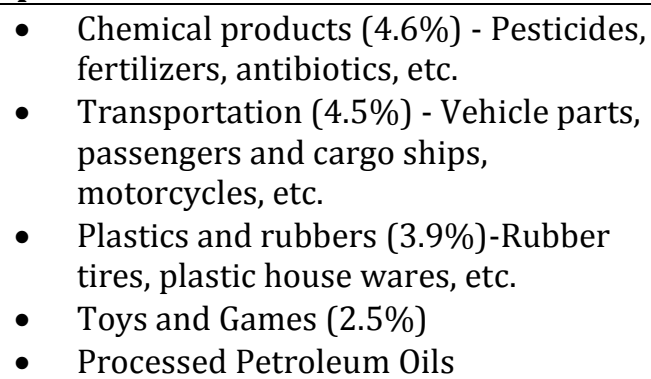 \\
\hline
\end{tabular}

(Source: iContainers, 2020)

Around one of the five Chinese exports ends up in the United States (19\%), Hong Kong (14\%), Japan (6.3\%), South Korea (4.6\%) and Germany $(3.2 \%)$, Vietnam $(3.9 \%)$, India $(3.0 \%)$, Netherlands (3\%), United Kingdom (2.5\%), Taiwan (2.2\%), Singapore (also 2.2\%) and Malaysia (2.1\%).. Overall, China's top 10 exports make up more than two-thirds of the overall value of its global shipments. Total Chinese exports make up $7.46 \%$ of the total world exports - an indication of the export dominance of the Asian giants(iContainers, 2020). Apart from the above products mentioned, China also has its dominance for the various services to the clients around the globe. During 2017, dollar amount is $4.3 \%$ of the global total for services, and represents about one-tenth $(10.1 \%)$ of the $\$ 2.263$ trillion in exported products China shipped over the same timeframe.China's exported services increased in value by $10.8 \%$ since 2013 and appreciated $8.9 \%$ from 2016 to 2017. Below are services exported by China in 2017 listed by category, considered commercial services and are worth $99.3 \%$ of all exported services from China.

\begin{tabular}{|c|c|}
\hline \multicolumn{2}{|c|}{ Table : 3: List of Chinese Services Exported within the World } \\
\hline $\begin{array}{ll}\text { - } & \text { Miscellaneous business services: US } \$ 61.5 \\
& \text { billion ( } 27 \% \text { of China's total) } \\
\text { - } & \text { Travel: } \$ 38.8 \text { billion }(17 \%) \\
\text { - } & \text { Transport: } \$ 37.1 \text { billion }(16.3 \%) \\
\text { - } & \text { Telecom/computer/information services: } \\
& \$ 27.8 \text { billion }(12.2 \%) \\
\text { - } & \text { Insurance/pension services: } \$ 4 \text { billion } \\
& (1.8 \%) \\
\text { - } & \text { Financial services: } \$ 3.7 \text { billion }(1.6 \%)\end{array}$ & 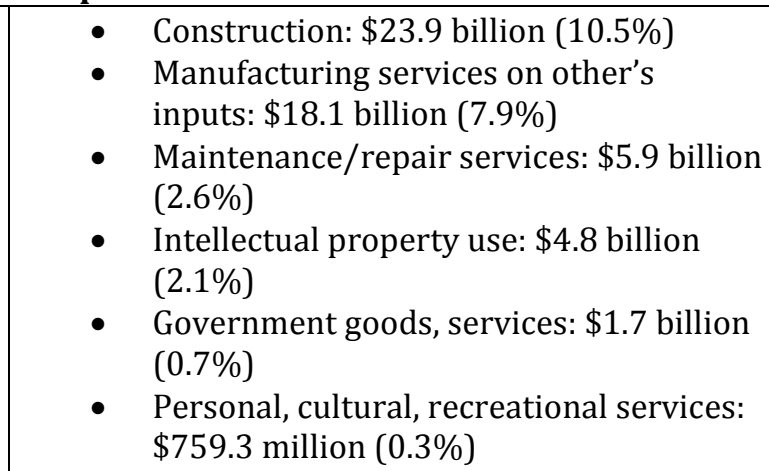 \\
\hline \multicolumn{2}{|c|}{$\begin{array}{ll}\text { (Source: Workman.D, } 19^{\text {th }} \text { February, 2019) } & \\
\text { From the above description regarding } & \text { of Chinese products and services existing within the } \\
\text { presence of Chinese Commodities and Services } & \text { Indian market, we find that the import from China } \\
\text { within the world market, it can be concluded that, } & \text { has significantly impacted our Indian manufacturing } \\
\text { China has the capacity to form stronger relation and } & \text { firms. While evaluating the various raw materials } \\
\text { become a global leader in terms of production and } & \text { imported from China it is found that India imports } \\
\text { distribution. In this tone if we focus upon the extent } & \text { include:- }\end{array}$} \\
\hline I dole: 4: List oi KaW iv & Idis mind rurcinds \\
\hline \begin{tabular}{ll|} 
- & Wrist watches \\
- & Wall Clocks \\
- & Ampoules \\
- & Glass rods and Tubes \\
- & Hair cream \\
- & Hair Shampoos \\
- & Face Powder \\
- & Critical Pharma Ingredients \\
- & Furniture
\end{tabular} & $\begin{array}{ll}\text { - } & \text { Eye and Lip Makeup preparation } \\
\text { - } & \text { Printing Ink } \\
\text { - } & \text { Paints and Varnishes } \\
\text { - } & \text { Tobacco Items } \\
\text { - } & \text { Cell Phones } \\
\text { - } & \text { Telecom } \\
\text { - } & \text { Plastic Toys } \\
\text { - } & \text { Mattresses } \\
\text { - } & \text { Electric Machinery }\end{array}$ \\
\hline
\end{tabular}




\begin{tabular}{l|l}
\hline Electronic Equipments & - Mineral Fuels \\
Chemicals & - Iron and Steel
\end{tabular}

List of Popular Chinese Apps used in India during the year 2019- 2020

- Tiktok (A short video sharing platform up to $1 \mathrm{~min}$ )

- PUBG (A popular battle royal mobile game)

- UC Browser (A mobile browser, owned by Alibaba)

- Helo (Social networking platform, developed by ByteDanvce)

- ShareIt (A popular file sharing app)

- V Mate (Video sharing app like tiktok)

- Xender (File sharing app which connect two smart phones)

- Cam Scanner (Popular scanning app)

- Beauty Plus (Photo editor and selfie filter app)

- U videos (video status platform that allows users to download various)

(Source: Times of India, June 22, 2020\& Jain. R, 8 June, 2020)

Thus, our country relies heavily on imports and according to Trading Economics, in 2015-16 exports increased $11.5 \%$ amounting to USD 160.68 billion, beating market expectations of a $2.5 \%$ rise. There has been a commendable growth in trade and commerce partnership between the two countries. India receives $3 \%$ of the total exports by Chinese. As per the report by FICCI, the Chinese have invested in the following Indian sectors:-Automobile Industry (40\%), Metallurgical Industry (17\%), Power (7\%), Construction (5\%), Services (4\%). In late 2000 s, 32 Chinese companies came together to form Chamber of Chinese Enterprises in India (CCEI). Companies make this move when they see a significant and potential market for trade. Another major organization which fosters relations between the two countries is the India China Chamber of Commerce and Industry (ICCCI). Due to the consistent growth in IndoChina business, there has been a constant demand for Chinese - English Translation Services and Chinese Interpreters, as officials from both countries travel to and fro for various meetings, trainings, and other such business trips (CMM Language, 2020).

\section{Demand for the Ban on Chinese Products within the World andHow Realistic is India's Boycott Campaign?} China is the largest country in terms of population and third largest in terms of territory sharing long border with many other countries. Border conflicts are very common and occurred many times as the history says as many of the ancient Chinese emperors tried to expand their empires through war. There are many on-going conflicts on national interests and policies between China and other nations. Other than such national conflicts, issues regarding Chinese low quality products and tailored market goods, leads to dissent against Chinese products and services within the world. Such dissent calls for the boycotting of China made goods. Many countries calls for boycott of China made goods by using the Covid-19 pandemic as a part of campaign against China. For example-

(a) Australia companies stopped importing cotton sourced from the Chinese province of Xinjiang after reports of human rights abuse in forced labour camps came to light and on the contrary wanted to support local business (Karp.P, $7^{\text {th }}$ May, 2020).

(b) United States, President Donald Trump, signed the National Defence Authorization Act for Fiscal Year 2019 into law, containing a provision that banned Huawei and ZTE equipment from being used by the U.S. federal government, citing security concerns (Nakashima. E, 11 th April, 2020)

(c) At United Kingdom, a group of lawyers and activists submitted a 60-page document urging the UK government to ban the import of all cotton from Xinjiang over concerns of "forced labour regime" in the province. A survey conducted in June 2020 revealed that $49 \%$ of British citizens would boycott "at least some Chinese products", while twothirds voted in favour of increasing tariffs on Chinese imports (Withnall.A, 23 ${ }^{\text {rd }}$ April, 2020).

(d) Vietnam also boycott China movement triggered due to the disputed areas near the South China Sea. Dispute arises due to the case of case of the HaiyangShiyou 981 standoff, that is Chinese stateowned China National Offshore Oil Corporation moving its Hai Yang Shi You 981 known in Vietnam as "HảiDương 981") oil platform to waters near the disputed Paracel Islands in South China Sea, and the resulting Vietnamese efforts to prevent the platform from establishing a fixed position leads to violent clash between 
China and Vietnam army (Nguyen. T, $16^{\text {th }}$ October, 2014).

(e) Philippines also joined the group regarding boycott of Chinese product. Albay Gov. JoeySalceda, a Filipino politician supported boycott of Chinese product over the disputed issue of Spratly Island, where China installed some military structures on more reefs in the vicinity of the Philippines occupied islands and this led to escalating tensions between these countries and China over the status and "ownership" of reefs (Asia News Network, $13^{\text {th }}$ June, 2011)

(f) Tibet Government had also called for boycott Chinese products, under the leadership of Civil Right Activist, ThuptenNorbu. According to him he is confident that the campaign to boycott Made-in-China products will gain the support of freedom loving people around the world, and will eventually succeed in forcing China to respect the rights of its own people and acknowledge Tibetan independence (Student for Free Tibet

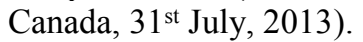

(g) In India, the slogan 'Boycott China' is not just a slogan anymore; it became the emotion running across the length and breadth of India. Engineer who turned education reformer and became more focused after the movie ' 3 Idiots', SonamWangchuk has said that if China has to be dealt with, then India needs to attack its economy. He too added further that while the Chinese in border areas can be handled by the Army, the Chinese invasion in Indian market can be dealt only with the cooperation of general public (Wangchuk. S, 6 $6^{\text {th }}$ June, 2020). Similarly,

RashtriyaSwayamSevakSanghSarsangcha lak (Chief), Mohan Bhagwat stated that "we speak about self-dependence and standing up against China. The new government seems to be standing up to it. But where will the government draw strength from if we don't stop buying things from China" (India Today, $3^{\text {rd }}$ October, 2014).

Amidst of such national sentiment calls across India, if we take a time please for a while and evaluate on how realistic for Indian economy to completely withdraw Chinese products. Here is a look at decade long India-China relationand what is at stake for Indians economically in relation to boycott camping.

(i) Hindi-Chini Bhai-Bhai: During 1950's leaders of older generation of two countries made the historical decision to establish diplomatic relation and jointly advocated "Indians and Chinese are Brothers". India was the first country to recognise People's Republic of China has the legitimate government of the main land China. The SilkTrade-Route served as a major trade rode between the two countries. Relations between contemporary China and India has been characterised by several border disputes. 1962 Sino-Indo War, 1967 Chola Incident and 1987 Sino-Indian Skirmish are some of the landmark border disputes. Since, then from 1988 both the countries are continuously trying to rebuild the economic relation among them.

In 1988, Indian Prime Minister Rajiv Gandhi visited China, initiating the process of normalization of bilateral relation. The two sides agreed and looked forward. In 1933, Indian Prime Minister NarasimhaRao visited China Agreement between the government of China and government of India on the Maintenance of Peace and Tranquillity along the line of actual control in Indian-China Border Area was signed. In 1966, Chinese President Jiang Zemin visited India to establish bilateral ties to build a constructive partnership of co-operation towards $21^{\text {st }}$ century. In 2009, Indian Prime Minister Vajpaye visited China; two sides signed the Declaration on the Principles and Comprehensive Cooperation upon ChinaIndia relation. In 2008, Indian Prime Minister Dr.Manmohan Singh visited China and "Shared Vision for $21^{\text {st }}$ Century" was agreed upon by both the governments. In 2013, President Xi Jinping met with Indian Prime Minister Dr.Manmohan Singh on the side lines of the $5^{\text {th }}$ BRICS Summit in Durban, South Africa in March. Ultimately, 2014 came to known as the China-India Friendly Exchange Year. In September same year President Xi Jinping paid a state visit to India and Visited Indian Prime Minister home state Gujrat. The two sides issued joint statement on building a closer development partnership in the name of "Home-Town Diplomacy". This partnership was accordance with mutual trust, managing differences and seeking common development.

(Source: The Hindu, $31^{\text {st }}$ March, 2020)

(ii) Hindi-Chinni Buy-Buy:China is India's largest source of import by some distance. In 2018-19 India imported goods worth $\$ 88$ billion from China. This was more than $17 \%$ of India's total imports. On the other hand, only exports around $\$ 30$ billion worth of 
goods to China. What makes this balance worse is the nature of what India exports to china verses what it imports. "we export mostly raw materials and low value items to China, but we import value added items as discussed in the above tables 2 and 4 .

The Indian consumer's interest in Chinese goods always remained high, as for example five top smart phone sellers -Xiaomi, Oppo, Vivo and Realme in India are Chinese. This means three out of every four smart phone sold in India during 2019-2020's $1^{\text {st }}$ quarter, were Chinese. A similar situation exists in the smart TV market, where Xiaomi is the market leader with massive $27 \%$ of market share. Such domination also extends across rural markets of India, especially in the agricultural sector. As much as $45 \%$ of Phosphate Fertilizers and 13\% of Urea is imported from China. Any effort to boycott China in this sphere will mean a substantial hike in prices for Indian farmers. In some cases, restricting imports of China would significantly impact upon Indians health.As the companies like AratiDurgs, Granules India, JB Chemicals, IOL Chemicals are worth tracing as more than half of raw material regarding anti-biotic are imported from China.

As per the March, 2020 report published by Gateway House, 'Indian Council on Global Relations, 'lists major Indian Companies with substantial holdings form Chinese Investors. China's Tech Company and Venture Capitalist investment in India account for more than $\$ 3,600$ million on one hand, whereas, on the other hand, the report also states that most Indian financers cannot make $\$ 100$ million commitments needed to finance start-up though their early losses. For instance PayTm incurred a loss of Rs. $3,690 \mathrm{cr}$. in financial year 2019 while Flipkart lost Rs. 3,837 cr. over the years, which leaves western and Chinese investors as dominant players in Indian start-up space. Thus, at this point when Indian economy is shrinking due to coming of Covid-19 and its related shadow called lockdown, any calls to break economic ties may lead to crisis situation. Presently, when many Indian manufacturer, factories and agricultural spare are incurring losses due to 5 phases of lockdown, the question arises, how it will be possible to gain self-reliance at a time when common man purchasing power has fallen rapidly.(Source: Daniyal.S, 23 ${ }^{\text {rd }}$ June, 2020 \&Tripathi.S, $15^{\text {th }}$ June, 2020)

(iii) Hindi-Chini Bye Bye:The recent bitter stand-off between India and China within the
Gulwan valley and subsequently Indian Prime Minister NarendraModi'smessage seemed to have renewed across India. Today in India people are showing anger and disliking towards Chinese commodities. Common people of Indian are demanding that government should cancel the contract given to Chinese Companies and future Indian government should not give new contracts to China. As when our Indian soldiers are sacrificing their life in the border, these Chinese companies are making huge profits from the contracts.(Source: DNA Analysis, Zee News Desk, $18^{\text {th }}$ June, 2020)

Thus, the above explanation of the India-China political and economic relation clearly depicts that how much India is dependent on China. Therefore, main focus here it is to emphasise that the height of opportunity for India is huge and it's also high time for India to focus upon its local business.

\section{Atmanirbhar Bharat (Self-Reliant India) Movement: A Dynamic Concept:}

Self-Reliant India is a movement which turned into an opportunity for India to fight against the present crisis evolved due to pandemic. The term was originally coined by Indian Prime Minister NarendraModi, during his address to nation on $12^{\text {th }}$ May, 2020. He also defined five pillars of Aatmanirbhar Bharat that is Economy, Infrastructure, System, Demography and Demand. He stressed upon the fact that it is time to become vocal for our local products and make them global. Under this campaign, a special economic package has been released by the government, which will benefit various segments including cottage industry, Micro, Small and Medium Enterprises (MSMEs), labourers, middle class, and industries, among others. It is expected to provide support and strength to various sections of the country and give a renewed boost to the development journey of the country in 2020. Minister of Finance \& Corporate Affairs, Ms NirmalaSitharaman made all the announcements related to various sectors on different days, split under five tranches and giving detailed information about the steps being carried out by the government (IBEF, 20 $0^{\text {th }}$ May, 2020). The five tranches are:

Trance 1- In the first tranche, Sitharaman announced a list of 15 measures. Putting emphasis on PM's concept of Atmanirbhar India (self-reliant India) she mentioned that the focus of the package is on the factors of production- land, labour, liquidity and others. The first measure being focussed on was the idea of getting back to work i.e., facilitating employees and employers, businesses, especially MSMEs, to get back to production and workers back 
to gainful employment. Plans to strengthen NonBanking Financial Companies (NBFCs), Housing Finance Companies (HFCs), Micro Finance Sector and Power Sector were also unfolded.

Trance 2- Asa part of the second tranche, nine main measures to aid migrant workers, street vendors, small farmers, self-employed people were announced.

(a) Migrants: Free food-grain supply to all migrants for the next 2 months- Free food-grain supply to all migrants for the next 2 months. Non-Cardholder Migrants shall be given $5 \mathrm{KG}$ rice/wheat \& $1 \mathrm{KG}$ lintel per family for 2 months. One nation one ration card in three months- National portability of ration card with 'one Nation one ration card' will be implemented by August this year

(b) Shishu Loan under MUDRA: 2\% interest reduction for Shishu loans under MUDRAWhile loan moratorium has already been granted by the SBI, a 1500 crore interest subvention for MUDRA has been announced. The Centre will provide interest subvention of $2 \%$ for prompt payees for a period of employees.

(c) Street Vendors: Rs. 5000 Credit facility for street vendors-Rs. 5000 crore special credit facility for street vendors which will benefit 50 lakh street vendors. They will receive an initial working capital up to Rs. 10000, within a month.

(d)Housing: Extension of CLSS till March 2021- 70,000 crore boost to housing sector \& middle income group through the extension of Credit Linked Subsidy Scheme (CLSS) by extending the scheme till March 2021.

(e) Tribals: Employment via Rs 6000 crore CAMPA funds- Employment for tribals via Rs. 6000 crores using Compensatory Afforestation Management \& Planning Authority (CAMPA) Funds.

(f) Farmers: Emergency working capital fund via NABARD, 30,000 croreadditonal emergency working capital funding for farmers via NABARD (National Bank for Agriculture and Rural Development). Moreover 2 lakh concessional credit boosts for farmers- Farmers holding Kisan Credit Cards will be provided concessional Credit boost amounting to Rs. 2 lakh crore. Fishermen \& Animal husbandry farmers will also be included in this

Trance 3-Finance Minister NirmalaSitharaman announced 11 measures - of which 8 of them focused on strengthening infrastructure, capacities and building better logistics in Agriculture, Fisheries and animal husbandry, while the rest 3 pertained to governance and administrative reforms.
Trance 4- The Centre announced structural reforms in eight sectors in the fourth tranche of its economic package amid Coronavirus lockdown. The reforms introduced affect 8 sectors namely - Coal (commercial mining in coal sector), Defence Production (Corporatisation not privatisation of ordnance factory board), Minerals (Seamless exploration-cum-mining-cum-production regime), Civil Aviation (airports, airspace management and maintenance, repair and overhaul), Power Sector(power distribution in Union territories to be privatised), Social Sector ( Social infrastructure to be revamped though viability gap funding scheme) Space and atomic energy (private participation boost in space exploration and other atomic energy-related reforms).

Trance 5- In the fifth and the last tranche of the Aatmanirbhar Bharat package, Finance Minister NirmalaSitharaman announced 7 steps namely for MNREGA, health and education, for states, and for easing of business. These Steps are:

1. Rs. 40,000 croresincrease in allocation via Mahatma Gandhi National Rural Employment Guarantee Act (MNREGA) to provide employment boost.

2. Health reforms and other initiatives, under which public expenditure will be increased. Moreover, a programme for technology driven education will be launched immediately.

3. Enhancement of ease of doing business through International Business Corporation (IBC) related measures. Even special insolvency related framework for Micro Small, Medium Enterprises (MSME's)

4. Decriminalisation of Companies Act defaults- Decriminalisation of Companies violation involving minor technical and procedural defaults, de-clogging the criminal court and shifting of compoundable offence section under internal adjudication mechanism (IAM).

5. Ease of doing business, under which there will be direct listening of securities by Indian public companies in permissible foreign jurisdiction. As well as empowering central government to exclude Covid-19 related debts from the definition of default.

6. Public Sector Enterprise Policy for a new Self-Reliant India, where all sectors are open to the private sectors, while Public Sector Enterprises (PSE's) will play important role in defined areas.

7. Supporting State Governments, centre has decided to accede to the request and increase borrowing limits of State from 3\% to $5 \%$ for 
2020-21 only, in view of the unprecedented situation.

(Source:Verma.A, 17 $7^{\text {th }}$ May, 2020)

Thus, world's expectation from India has increased and we Indians must take the opportunity and should turn it into our advantage. We can see that ramping up of manufacturing of Personal Protective Equipment (PPE) over the last three months was a positive step. India is continuously making effort to reduce import dependence in sectors such as mobile and defence manufacturing. Therefore, today we should try to focus on creating strong enterprises, which can become a global image for India. World is looking for a trusted partner and India has the ability to emerge as one (Economic Bureau, $3^{\text {rd }}$ June, 2020). Various brands in the world have viewed boycott and acceptance by much nationalistic movement in the past as well. Such decision has always led to gamechanging market scenario. For example-the rise of PantajaliAyurved in the Indian market is the fastest growing company in FMCG sector. Like Unilever, Procter \& Gamble, Nestle, Colgate-Palmolive, Johnson \& Johnson. Patanjali manufactures from shampoo to biscuits to ghee and noodles and even medicine, no other company has built such a welldiversified product portfolio. At this juncture, it is no surprise that the American business magazine Fast Company ranked Baba Ramdev 27th in its list of "Most Creative Business People of 2016", While AchrayaBalkrishna has made his debut on the Forbes list of India's 100 Richest people at $48^{\text {th }}$ position (Maheshwari.R, 25 th June, 2020).

Hence, in order to sustain the momentum of local business, India has to focus on certain keytake ways as:-

- Low pricing and cost dynamics that is providing attractive discount compared to the competitive brand should be the beginning. As large part of Indian population is mostly price sensitive in nature rather than quality product.

- Focusing upon Indigenous marketing strategy, through which company can say that the products are made from handpicked and hand-made organic raw material.

- As, India is a vast country and second in terms of population, therefore local business should develop a proper vendor system and distribution channel. Such development will help the business to reach every corner of the country.

- Due to its position of second most populous country in the world, the local business merchants can turn it into opportunity. The business can hire right indigenous talent and can help to mitigate unemployment problem.

- Moreover, Indian business merchants also develop a culture which is the combination of tradition and technology. Such culture combination can create a strong brand image in the world market.

- Ultimately, our country base is not corporate culture, rather people view India as a religious based country, where rituals play very important role. Hence, local business should provide importance on this spiritual and religious aspect of the country. Business man should advertise its product as extremely Indian and culturally rooted.

\section{CONCLUSION OF THE STUDY}

The present study provides a bird eye view of how China become the market leader, presence of Chinese products within the world and Indian Market and how India can overcome the dependency by becoming self-reliant. The study also provide certain unconventional marketing strategies for India and how following these Indian industries can revolutionize in a record time. While this study has its limitation as it focuses mainly upon India-China socio-economic relation, but still hope that it can serve as a basis for future study in consumer boycott consumer.

\section{REFERENCES}

1. Asia News Network, (13 $3^{\text {th }}$ June, 2011), "Philippine governor calls for boycott of 'Made in China' products", Asia One, A Singapore Press Holding Portal, Available online at URL: https://web.archive.org/web/20141021160008/htt p://news.asiaone.com/News/Latest\%2BNews/Asi a/Story/A1Story20110613-283760.html

2. Bajpai. P (13 $3^{\text {th }}$ February, 2020), "Why China Is the World's Factory", Investopedia, available online at URL: https://www.investopedia.com/articles/investing/ 102214/why-china-worlds-factory.asp

3. Bada Business (10 ${ }^{\text {th }}$ August, 2019), "How China Became an Economic Super Power", an initiative by Dr.VivekBindra, Available online at URL:

https://www.badabusiness.com/articles/howchina-became-an-economic-superpower/

4. CSIS (17 $7^{\text {th }}$ March, 2020), Centre for Strategic and International Studies, China Power Project, 1616 Rhode Island Avenue, NW, Washington, DC 20036, Available online at URL: https://chinapower.csis.org/trade-partner/

5. CMM Language, (2020), "Top Chinese Companies India", CMM language.com, Translation Company, Available online at URL: http://www.cmmlanguages.com/top-chinesecompanies-in-india.html 
6. Daniyal. $S$ (23 ${ }^{\text {rd }}$ June, 2020), "Sino satyagraha: Can India 'boycott China' as a response to the Ladakh attack?" Scroll.in, Available online at URL: https://scroll.in/article/965167/sino-satyagrahacan-india-boycott-china-as-a-response-to-theladakh-attack

7. DNA Ananlysis, Zee News Desk (18 $8^{\text {th }}$ June, 2020), "हिंदीचीनीभाई-भाईनहींयेहिंदीचीनी Bye-

Byeकहनेकावक्तहै', Available online at URL: https://zeenews.india.com/hindi/india/dnaanalysis-its-time-to-say-hindi-cheeni-byebye/697470

8. Embassy of India, Beijing, China (2019), "India -China Trade and Economic Relations, Available at URL: https://www.eoibeijing.gov.in/economicand-trade-relation.php

9. Economic Bureau (3 $3^{\text {rd }}$ June, 2020), "India will get its growth back, need to be self-reliant: PM" The Indian Express,english daily news paper, Sunday $28^{\text {th }}$ June, 2020, Available Online at URL:

http://indianexpress.com/article/business/econom y/pm-narendra-modi-self-reliant-cii-annualsession-2020-6439770

10. Greven.M.J\&Wei.W (January, 2017), "Business Ecosystem in China: Alibaba and Competing Baidu, Tencent,Xiaomi and LeEco", Research Paper, Available online at URL https://www.researchgate.net/publication/324818 839_Business_ecosystems_in_China_Alibaba_an d_competing_Baidu_tencent_Xiaomi_and_LeEco

11. iContainers (2020), "What does China Export", iContainers, A Global Freight Forwarder, Available online at URL: https://www.icontainers.com/us/2017/12/05/what -does-china-export/

12. India Today (3rd October, 2014), "Boycott Chinese goods, says RSS Chief Mohan Bhagwat in DD telecast”, a leading English News Channel, Available online at $U R L$ :

https://www.indiatoday.in/india/story/mohanbhagwat-says-ban-chinese-goods-rss-chief-ddtelecast-208510-2014-10-03

13. IBEF- India Brand Equity Foundation (20 ${ }^{\text {th }}$ May, 2020), "Self-Reliant India Movement and Opportunity", Available online on URL: https://www.ibef.org/blogs/self-reliant-indiamovement-an-opportunity

14. Jain. $R$ ( $8^{\text {th }}$ June, 2020), "These are Top 10 popular Chinese Apps in India in 2020", Business Insider, Available online at URL: https://www.businessinsider.in/tech/apps/news/ch eckout-the-top-10-popular-chinese-apps-inindia-in-2020/slidelist/76253572.cms

15. Kumar.T (15 th October, 2016), "Boycott Chinese Goods? Here's a Reality Check", The Quint, Available online at URL: https://www.thequint.com/videos/boycottchinese-goods-heres-a-reality-check-tradeiphone-macbook-apple-motorola-made-in-china

16. Karp. $P$ ( $7^{\text {th }}$ May, 2020), "China's Coercive Behavior a 'Wake-up call', Australia's Formet Top public servant says", The Guardian, Available online at URL: https://www.theguardian.com/australianews/2020/may/08/chinas-coercive-behaviour-awake-up-call-australias-former-top-publicservant-says

17. Kangwon National University (2016-2017), "What Western Marketers Can Learn from China", Avialable online at URL: https://www.studocu.com/ko/document/kangwonnational-university/businessadministration/\%EA\%B0\%95\%EC\%9D\%98 $\% E D \% 95 \% 84 \% E A \% B 8 \%$ B0/what-westernmarketers-can-learn-from-china/6099488/view

18. Lee.Y.N (23 ${ }^{\text {rd }}$ September, 2019), "Here are 4 charts that show China's rise as a Global Economic Superpower", CNBC, Available online at URL: https://www.cnbc.com/2019/09/24/howmuch-chinas-economy-has-grown-over-the-last70-years.html

19. Mundra. S (1 $1^{\text {st }}$ November, 2016), "Reality Check: Open letter to Baba Ramdev on his call to Indians to Boycott Chinese Products", The Week, Available online at the URL: https://www.theweek.in/youzone/openletter/open-letter-baba-ramdev-boycott-chinesegoods.html

20. Maheshwari. $R$ (25 th January, 2017), "The Epic Rise of Patanjali: Game Changer in Indian FMCG Industry" Mystory, Available online at URL: https://yourstory.com/mystory/c5edeadc03the-epic-rise-of-patanjali-game-changer-inindian-fmcg-industry

21. Nakashima. E (11 $1^{\text {th }}$ April, 2020), "Trump administration moves against Chinese telecom firms citing national security", The Washington Post, Available online at URL: https://www.washingtonpost.com/nationalsecurity/trump-administration-moves-againstchinese-telecom-firms-citing-nationalsecurity/2020/04/10/33532492-7b24-11ea-9beec5bf9d2e3288_story.html

22. Nguyen.T (16 th October, 2014), "Vietnamese Businesses Urge Boycott on Low-End Chinese Products", VOA News, Available online at URL: https://www.voanews.com/east-asia/vietnamesebusinesses-urge-boycott-low-end-chineseproducts

23. Sharma. P (15 th May, 2020), "How the World is forming an Alliance against China", WION, Available online at URL: https://www.wionews.com/world/how-the-worldis-forming-an-alliance-against-china-298934

24. Wangchuk.Sonam (6 $6^{\text {th }}$ June, 2020), "Help me Change China: With Wallets rather than Bullets" [Video], Available online at URL: https://www.youtube.com/watch? $v=n n V s W t 2 P C 4$ $w$

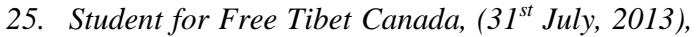
"Boycott Made in China", Transforming World Through Non-violent Action, Available online at $U R L$ :

https://web.archive.org/web/20141016013014/htt $p: / / w w w . s f t-$ canada.org/campaigns/economic/boycott-madein-chinal 
26. Singh. $S\left(25^{\text {th }} \quad\right.$ June, 2018), "China-India Bilateral Trade: Strong Fundamentals Bright Future", China Perspective, an open journal, Available online at URL:https://journals.openedition.org/chinapersp ectives $/ 2853$

27. The Economic Times ( $3^{\text {rd }}$ April, 2020), "India, China trade declines by 12.4 per cent in first two months of this year amid coronavirus outbreak", Available online at URL: https://economictimes.indiatimes.com/news/econ omy/foreign-trade/india-china-trade-declines-by12-4-per-cent-in-first-two-months-of-this-yearamid-coronovirusoutbreak/articleshow/74970477.cms? from $=m d r$

28. Times of India (June 22 $\left.{ }^{\text {nd }}, 2020\right)$, " "Govt Seek Product-Wise Detail form Industry to curb Cheap, low Quality Imports from China", Available online at URL: https://timesofindia.indiatimes.com/business/indi a-business/government-seeks-product-wisedetails-from-industry-to-curb-cheap-low-qualityimports-from-china-

sources/articleshow/76495007.cms

29. The Hindu (31 $1^{\text {st }}$ March, 2020), "70 years of Diplomatic Relations between China and India (1950-2020)", the leading News Paper, Available online on URL: https://www.thehindu.com/brandhub/70-years-ofdiplomatic-relations-between-china-and-india1950-2020/article31219737.ece

30. Tripathi.S (15 th June, 2020), "Is it Realistic for India to Boycott Chinese Products, Investments?" ETNOWNEWS.COM, Available online at URL:

https://www.timesnownews.com/businesseconomy/economy/article/is-it-realistic-for-indiato-boycott-chinese-products-investments/606752

31. Verma. A (17 $17^{\text {th }}$ May, 2020), "These Are All 5 Tranches and 50 Measures Of India's Aatmanirbhar Bharat' Economic Package", Republic World, Available online on URL: https://www.republicworld.com/indianews/economy/full-aatmanirbhar-bharatpackage-5-tranches-50-measures-details-he.html

32. Wen. Y (12 ${ }^{\text {th }}$ April, 2020), "Chinese Rapid Rise: From Backward Agrarian Society to Industrial Powerhouse in Just 35 Years", Federal Reserve Bank of St. Louis, Available online at URL: https://www.stlouisfed.org/publications/regionaleconomist/april-2016/chinas-rapid-rise-frombackward-agrarian-society-to-industrialpowerhouse-in-just-35-years

33. Withnall. A (23 ${ }^{\text {rd }}$ April, 2020), "UK government urged to ban import of Chinese cotton "made using Uighur Muslim forced labour", Independent News, Available online at URL: https://www.independent.co.uk/news/uk/homenews/chinese-cotton-uk-government-importantuighur-muslim-labour-a9478501.html

34. Workman.D, (19 $9^{\text {th }}$ February, 2020), “China's Exported Services", World's Top Exports, Available online at URL: http://www.worldstopexports.com/chinasexported-services/ 